\title{
A Study on EFL Teaching Affecting Chinese Cultural Tourism
}

\author{
Onsiri Wimontham \\ English Education, Faulty of Humanities and Social Sciences, Nakhon Ratchasima Rajabhat University, Thailand
}

\begin{abstract}
This research article is focused on presenting research studies related to English teaching as a foreign language in educational institutes; secondary and higher education levels in China so as to acquire whether there is weakness and strength or not. This research is conducted in Thailand and Beijing municipality, People's Republic of China. The duration of research is 90 days; 80 days in Thailand and 10 days in People's Republic of China. The sample size of 30 persons is chosen with the purposive sampling method. The research instruments consist of questionnaire, focus group interview and evaluating form from participatory. The researcher conducts analysis for both qualitative and quantitative data with a SWOT analysis technique; strengths, weaknesses, opportunities, and threats. The research was found that the summary of opinion of youths who live in Beijing towards the importance of using English to elevate and develop cultural and wisdom tourism, The summary of Chinese youths' opinion towards the teaching and learning curriculum management of English for communication in Beijing municipality, secondary education level, The summary of level of Chinese youths opinion towards the teaching and learning curriculum management of English for communication in Beijing municipality, in a higher education level.
\end{abstract}

Index Terms - English teaching, curriculum, secondary and higher education

\section{INTRODUCTION}

This research article is focused on presenting research studies related to English teaching as a foreign language in educational institutes; secondary and higher education levels in China so as to acquire whether there is weakness and strength or not. Emphasis is placed on a study of state of problem based on many research studies indicating that most Chinese people are unable to use English language for communication. Though Chinese people have studied English, averagely 10 years per person, they cannot use English for communication with foreigners. With regards to this problem, in 2015 the Chinese government ordered Ministry of Education to draft a policy in encouraging people of all ages in the country, especially youths, to be able to pass placement tests of English for communication. Meanwhile, the Ministry of Education specifically arranges English Proficient Test Center (EPTC) to measure English literacy of Chinese people. However, based on the summary and processing test results in June 2016 and 2017, it was found that Chinese youths who attended EPTC whose age is between $15-21$ had moderate degree of test results; $(\overline{\mathrm{X}}=3.30)$ and $(\overline{\mathrm{X}}=3.38)$ espectively.

With regards to the evaluation results mentioned above, the researcher is interested in conducting a research study concerning the state of problem about teaching and learning English as a foreign language that continually happens in China whose problem is similar to that of in Thailand as it is found that though teaching and learning English has been provided since kindergarten level, when people graduate from a higher education level and enter to the job market, most of Thai population cannot use English for communication efficiently. The research result from Anuwat Singsiri (2015:78) revealed that the reason that youth and working population in Thailand cannot use English for communication though they have studied it for such a long time is that the educational system, curriculum and quality of teachers are not up to the standard they should be. Moreover, factors concerning budget allocation for employing foreign teachers holding teaching experience and professional mother-tongue teachers are not sufficient to meet the domestic demand.

The mentioned research result initiates the researcher to study about a model of teaching English as a foreign language in Beijing municipality, People's Republic of China so as to acquire which aspects curriculum users; school and university students, require from the government to improve and support budget in teaching and learning that will be beneficial to English teaching and learning affecting cultural tourism in Beijing municipality, People's Republic of China. Besides, the researcher would like to compare similarity and difference of a model of teaching English as a foreign language between China and Thailand in order to develop English education curriculum, Bachelor of Education, Nakhon Ratchasima Rajabhat University, Thailand for producing students to be qualified teachers to meet demand of educational institutes and be teachers who can teach students to use English efficiently in accordance with the standard governed by The Teachers Council of Thailand. In addition to the mentioned purposes, the researcher would like to study an English teaching guideline in China that supports creative economy framework development plan as stated in economic and social development plan of People's Republic of China for the year 2016 - 2020 to join the high-income countries. The $4^{\text {th }}$ development part, the $6^{\text {th }}$ section determined that youths and working population are the role model 
who can use English language for welcoming international tourists efficiently so as to develop tourism economy of Beijing municipality to gain higher statistical development level with GDP 5.2 rising increasingly from the economic statistics in February 2015.

\section{LITERATURE REVIEW}

\section{A. Educational System in China These Days}

China' s education system is set up by the central government and Ministry of Education is the supreme education administration body, which is responsible for carrying out related laws, regulations, guidelines and policies of the central government. All citizens must attend schools for at least nine year, known as the nine-year compulsory education; 6 years in elementary education level, and 3 years in junior secondary education level. It can be said that in China, the education is divided into 4 categories: 1) basic education, 2) vocational education, 3) higher education, and 4) adult education.

1. Basic education refers to primary education ( 6 years), junior and senior secondary education (6 years). The Chinese government gives high importance to basic education; the primary education starts at the age of 6 according to the compulsory education law.

2. Vocational education includes short term training courses. After 1980, the vocational education in China has been rapidly developed. At present, a situation of the growth of vocational education is changed; a study about fiscal policy, physical education and fine arts has a tendency to increase while a study in science seems to be declined. In 2005, there were about 6 millions students in vocational education.

3. Higher education means diploma degree, a bachelor's degree, a master's degree and all degree level education. Diploma degree education takes $2-3$ years and the bachelor's degree requires 4 years. A bachelor of medicine takes 5 years similar to other fields, a master's degree take 2-3 years while a doctoral degree takes 3 years.

4. Adult education means different educations set up for adults and those who are not literate or other educations having similar models.

\section{B. Model of English Teaching in China}

English teaching approaches in China are similar to many countries having the model stressed on using English as a foreign language. The teaching models can be concluded as follow:

1. Grammar-translation method: it is an approach stressed on grammar rules and translation acts as an intermediary to enable students to understand lessons. Teachers tell and describe the rules and exception to students for memorizing including proper nouns and assign students to practice exercises being in line with those grammar rules. With regards to vocabulary, teachers teach many vocabularies at a time by telling Chinese translation words but do not ask students to use those vocabularies in sentences. Next, teachers ask students to write down each word in their notebooks, tell the meaning of each word while sometimes students are told to write down pronunciation. Teachers focus on reading and writing skills and measurement emphasizes on knowledge, memorizing, vocabularies, rules, and ability in translation. Teachers play important roles in this model and students can be only listeners.

2. Direct method: it is a teaching method focusing on listening and speaking skills to make understanding and then practicing reading and writing skills. It is believed that when students can listen and speak, they will be able to read and write more easily and faster. Therefore, most lessons comprise dialogue activities that allow students opportunities to use language to a great extent. Teachers play their roles in encouraging students to speak interactively and creating learning atmosphere or using instructional media that can support teaching and learning atmosphere. This method does not stress on grammar or rules. Teaching vocabulary is relied on describing a certain word in English while probably using instructional media or authentic materials to support teaching. Emphasis for measurement is placed on listening and speaking such as following instruction, pair work speaking activities, dictation, etc.

3. Audio-Lingual method: it is a teaching method based on linguistics and the structural view of language. The teaching is relied on natural approach; listening, speaking, reading, and writing, starting from simple to difficult things. Learners have to practice language repetitiously until they get familiar with and can speak automatically. Teachers have to be a good role model in using correct language for learners to imitate. Learners follow and practice what teachers teach from simple to difficult things. Teachers gather vocabularies and arrange in sentences so that learners can repeat after in different patterns. Emphasis is placed on practicing sentences rather than benefits. It can be seen that this method is not teaching for communication but for learning language in a classroom only.

4. Cognitive Code Learning Theory: this teaching method is based on the concept that language is a system of rules, understanding and expression. Once learners understand the form and meaning of language, they will be able to use language. As a result, teaching emphasizes all skills from the beginning without practicing listening and speaking before reading and writing as executed in the audio-lingual method. It depends on different requirement of learners. If learners would like to practice reading skill more than other skills, reading skill can be taught first. It is teaching that support learners to use their thought, intelligence, and have positive attitude towards English learning. Thai language plays important role in describing so that learners can speedily understand. This teaching method is similar to grammartranslation method that emphasis is placed on understanding and grammar rules but different in that this method gives 
importance to listening-speaking. Measurement and evaluation in learners' language competence is based on fluency of language in each step.

5. Individualized Instruction: In relation to English teaching evolution, it can be seen that learners gradually turn their roles as receivers only to be participants in teaching. The teaching has been changed from teacher-centered to be student-centered approach. Teachers make attempt to allow students to explore knowledge according to their abilities as much as they can while teachers provide instructional media. With reference to self-study, teachers probably prepare guideline documents where correct answers are provided or assign students to find answers by themselves from programmed instruction, individualized instruction, computer-assisted instruction, and television-assisted instruction. Moreover, teachers may provide instructional media for students to learn on their own such as learning vocabularies from surrounding environments, etc.

6. Total Physical Response Method: this teaching approach gives importance to listening for understanding. Once listeners understand what they listen, they will be able to practice accordingly and remember well. In the beginning, students do not speak, they just only listen and follow instruction. Teachers play their role in directing students' behavior. When teaching is implemented for a while and students are ready to speak, teachers will then make a command to students, reading and writing will be taught afterwards. Spoken language is used in teaching. Students learn grammar and sentence structure as well as vocabulary more than other aspects and adhere to command sentences; students can clearly understand from gestures or body language and teachers can immediately know whether students understand or not from their respond to those command sentences. So, in order to achieve the goal of this teaching method, in the first place teachers have to practice along with students. Later, teachers can give commands only and know how to arrange commands from simple to difficult level. Teachers should not give new command too soon; 3 new commands should be made at a time. When students understand clearly, the other new 3 commands shall be made such as "Walk to the door, touch the door, go back to your seat." More difficult commands can be made such as Pam, go to the window. Then, teachers tell the whole class as "If Pam goes to the window, class stand up, please take out the book, read the book, etc.

7. Discussion Method: it is a teaching approach leading students to realize working in a team and brainstorming to take problem solutions into account, find out facts, practice students to be able to express their opinion and have selfconfidence reasonably, practice students to be good listeners, well disciplined, patient to listen to other people's opinion. Teachers probably create a situation that students are going to attend a camping activity for 5 days and what kinds of items and personal belongings they have to prepare for it, teachers ask students to help make a discussion and summary in a form of a report and submit to teacher, etc.

8. Project Method: it is a teaching approach that allows students to attend an activity that students pay attention to or as assigned by teacher. Students implement their activities independently and teachers only suggest, assist, and follow up how students implement their activities; whether they can make any further progress or experience any obstacles or not, and teachers will evaluate students' achievement. This teaching method enables students to use language freely at a great extent and helps students possess good language development.

9. Community Language Learning: this teaching approach is different from others as it is a student-centered learning. Emphasis is placed on relationship between teachers and students, and relationship among students. Students feel that they are a part of a group. Each student is engaged in an activity and teachers become language advisors who encourage students to have creativity. Language usage focuses on communication, and what students learn can be applied in their everyday life. Students are taught to use sentence structures, vocabularies, and pronunciation according to the community language learning method without students' opposing. Teachers interact with their students at all times; relationship between teachers and students is considered very important. Learning outcome evaluation is conducted through an integrated evaluation method; students evaluate themselves by checking their learning and progress. If students make mistakes, teachers will make their attempt to correct those mistakes without threatening methods. Teachers probably correct mistakes by allowing students to repetitiously practice those tasks.

10. Communicative Approach: based on the fact, it has been found that though students learn thoroughly the structure of language, they cannot speak or communicate well. Consequently, linguists and those who involve with foreign language study oppose a new teaching approach-that is teaching for communication. It is believed that a language is not only a grammar system comprising pronunciation, vocabularies, and structure, but also a communication system. As a result, language teaching should enable learners to use language for communication. Learners should be taught to know not only models or structures of language since people use language as media for exchange and but also appropriate language usage in accordance with social situations through foreign teaching skills (English).

\section{Related Research Studies}

The researcher explored research studies related to this matter; William Bron (2014:145), a researcher from University of Hong Kong, conducted a research about teaching and learning English for communication in China for 6 months and found that students in elementary schools in China paid attention to teaching and learning English enormously since they had seen importance of English for communication with foreigners. However, students did not have self-confidence in using English for communication, with a moderate degree $(\overline{\mathrm{X}}=3.25)$. It was consistent with the research result about confident behavior in using English or other international languages for communication conducted 
by Ning Young Wong (2012:76), which found that students in higher education level in China had high achievement scores in English for further study but they did not have skills in using English for trade negotiation or English for service sectors, with a moderate degree $(\overline{\mathrm{X}}=3.43)$.

\section{SCOPE OF THE RESEARCH}

\section{A. Area of Study and Population in Research}

This research is conducted in Thailand and Beijing municipality, People's Republic of China. The duration of research is 90 days; 80 days in Thailand and 10 days in People's Republic of China. The population is youths who live in Beijing municipality, totally 978,452 persons. The sample size of 30 persons is chosen with the purposive sampling method. The researcher calculates the appropriate sample size without probability. Cochran's sample size formula is used to calculate the sample size with a 95 percent confidence level and a statistical significance level of 0.05 (Kanlaya, 2006, p.74).

The researcher chooses 3 institutes under the direction of Chinese Academy of Social Science (CASS), with purposive random sampling. Those 3 institutes are 1. Rural Development Institute, 2.National Academy of Social Development Strategy, and 3. Institute of Foreign Literature. A field trip is made to collect primary and secondary data in Beijing municipality.

\section{B. Research Instrument}

The instruments determined to collect primary data can be divided into 3 types as follow:

1. Questionnaire: there are 3 points determining the research framework in questionnaires related to this research articles as follow:

1.1 To summarize level of opinion of youths who live in Beijing municipality, People's Republic of China towards the importance of using English to elevate and develop cultural and wisdom tourism.

1.2 To summarize level of opinion of Chinese youths towards the curriculum for teaching and learning of English for communication in Beijing municipality, secondary education level,

1.3 To summarize level of opinion of Chinese youths towards the curriculum for teaching and learning of English for communication in Beijing municipality, higher education level. The data obtained from the questionnaires are analyzed results before and after research is conducted according to Yonin principle (2010:45)

2. Focus Group Interview and In Depth Interview are used on studying the potential, state of problems, and situation of teaching and learning management English as a foreign language.

3. Evaluating form from participatory process is employed the technique called "knowledge management and participatory process in developing teaching and learning curriculum of English as a foreign language in People's Republic of China" in a form of focus group according to the conceptual framework of Sin Panpinit (2008:90).

\section{Data Analysis}

The researcher conducts analysis for both qualitative and quantitative data with a SWOT analysis technique; strengths, weaknesses, opportunities, and threats. Descriptive statistic such as frequency and percentage is employed to arrange the importance of problems and requirement of situation analysis. The tendency of curriculum development is analyzed with SWOT analysis technique according to Wichai Wongyai ( 2007: 67).

\section{Language Used to Conduct the Research}

English Language

\section{STUDY RESULtS}

The researcher presents research results through 4 summary tables as follow

TABLE 1:

THE SUMMARY OF LEVEL OF OPINION OF YOUTHS LIVING IN BEIJING MUNICIPALITY OF PEOPLE'S REPUBLIC OF CHINA TOWARDS THE IMPORTANCE OF USING ENGLISH TO ELEVATE AND DEVELOPING CULTURAL AND WISDOM TOURISM

\begin{tabular}{|c|c|c|c|c|}
\hline Opinion & $\overline{\bar{x}}$ & S.D. & Level of importance & No. \\
\hline $\begin{array}{l}\text { English was more important for communicating with international tourist than } \\
\text { any other international languages. }\end{array}$ & 4.60 & 0.50 & Highest & 1 \\
\hline $\begin{array}{l}\text { English played an important role in elevating and developing cultural and } \\
\text { wisdom tourism of People's Republic of China. }\end{array}$ & 4.27 & 0.45 & Highest & 2 \\
\hline $\begin{array}{l}\text { English played an important role in helping tourists to access in-depth } \\
\text { information about culture and ancient traditions of People's Republic of China. }\end{array}$ & 4.17 & 0.38 & High & 3 \\
\hline $\begin{array}{l}\text { Youths living in Beijing municipality of People's Republic of China, were } \\
\text { capable of using English to communicate and facilitate international tourists. }\end{array}$ & 4.10 & 0.31 & High & 4 \\
\hline $\begin{array}{l}\text { Youths living in Beijing municipality of People's Republic of China were } \\
\text { capable of using English to nicely describe information about cultural tourism to } \\
\text { international tourists. }\end{array}$ & 3.93 & 0.37 & High & 5 \\
\hline Total & 4.21 & 0.46 & Highest & \\
\hline
\end{tabular}


TABLE 2:

THE SUMMARY OF LEVEL OF OPINION OF CHINESE YOUTHS TOWARDS TEACHING AND LEARNING CURRICULUM MANAGEMENT OF ENGLISH FOR COMMUNICATION IN BEIJING MUNICIPALITY, SECONDARY EDUCATION LEVEL

\begin{tabular}{|l|l|l|l|l|}
\hline Opinion & $\overline{\mathrm{x}}$ & S.D. & Level of importance & No. \\
\hline $\begin{array}{l}\text { Teaching and learning management emphasized the study of English } \\
\text { grammar. }\end{array}$ & 4.57 & 0.50 & Highest & 2 \\
\hline $\begin{array}{l}\text { Teaching and learning management had efficiency in enhancing listening, } \\
\text { speaking, reading, and writing skills }\end{array}$ & 4.33 & 0.48 & Highest & 3 \\
\hline $\begin{array}{l}\text { Teaching and learning management enhanced students to practice and have } \\
\text { hands-on experience in communicating with foreigners }\end{array}$ & 4.07 & 0.25 & High & 4 \\
\hline $\begin{array}{l}\text { The total hours of English subject earned sufficient credits to develop } \\
\text { English skills }\end{array}$ & 4.67 & 0.48 & Highest & 1 \\
\hline Measurement and evaluation emphasized communication achievement & 3.07 & 0.74 & Moderate & 5 \\
\hline $\begin{array}{l}\text { Measurement and evaluation focused on test scores achievement to further } \\
\text { study in a higher education level }\end{array}$ & 3.00 & 0.70 & Moderate & 7 \\
\hline Teachers had high level knowledge and skills in using English language. & 3.04 & 0.73 & Moderate & 6 \\
\hline Total & 4.14 & 0.77 & High & \\
\hline
\end{tabular}

TABLE 3:

THE SUMMARY OF LEVEL OF OPINION OF CHINESE YOUTHS TOWARDS TEACHING AND LEARNING CURRICULUM MANAGEMENT OF ENGLISH FOR COMMUNICATION IN BEIJING MUNICIPALITY, IN A HIGHER EDUCATION LEVEL.

\begin{tabular}{|l|l|l|l|l|}
\hline Opinion & $\overline{\mathrm{x}}$ & $\mathrm{S} . \mathrm{D}$. & Level of importance & No. \\
\hline $\begin{array}{l}\text { The total hours of English subject earned sufficient credits to develop } \\
\text { English skills }\end{array}$ & 3.30 & 0.47 & Moderate & 5 \\
\hline $\begin{array}{l}\text { Measurement and evaluation focused on test scores achievement to } \\
\text { further study in a higher education level }\end{array}$ & 4.43 & 0.94 & Highest & 2 \\
\hline $\begin{array}{l}\text { Teaching and learning management emphasized the study of English } \\
\text { grammar }\end{array}$ & 4.83 & 0.38 & Highest & 1 \\
\hline $\begin{array}{l}\text { Teachers had high level knowledge and skills in using English } \\
\text { language }\end{array}$ & 3.60 & 0.50 & Moderate & 3 \\
\hline $\begin{array}{l}\text { Measurement and evaluation emphasized communication } \\
\text { achievement }\end{array}$ & 3.53 & 0.51 & Moderate & 4 \\
\hline $\begin{array}{l}\text { Teaching and learning management had efficiency in enhancing } \\
\text { listening, speaking, reading, and writing skills }\end{array}$ & 3.28 & 0.45 & Moderate & 6 \\
\hline $\begin{array}{l}\text { Teaching and learning management enhanced students to practice and } \\
\text { have hands-on experience in communicating with foreigners. }\end{array}$ & 3.25 & 0.42 & Moderate & 7 \\
\hline Total & 3.94 & 0.83 & High & \\
\hline
\end{tabular}

TABLE 4:

THE OUTCOME OF PARTICIPATORY GROUP PROCESS MANAGEMENT TO SUMMARIZE THREATS AND GUIDELINES TO PROBLEM SOLVING ABOUT TEACHING AND LEARNING MANAGEMENT IN PEOPLE'S REPUBLIC OF CHINA

\begin{tabular}{|l|l|l|}
\hline No. & Threats & Guidelines to problem solving \\
\hline 1 & $\begin{array}{l}\text { Most Chinese youths could not use English for } \\
\text { communication, especially speaking skills. }\end{array}$ & $\begin{array}{l}\text { 1. The government should increase budget in employing more foreign } \\
\text { teachers of English, in particular teachers from countries using English } \\
\text { as a mother tongue. } \\
\text { 2. The teaching that emphasizes grammar or placement tests should be } \\
\text { decreased but more hours for teaching speaking for communication } \\
\text { should be increased. } \\
\text { 3. A curriculum of using English in real-life situations should be } \\
\text { increased so that students can practice using English in everyday life } \\
\text { naturally. }\end{array}$ \\
\hline 2 & $\begin{array}{l}\text { Most Chinese youths could not use English to } \\
\text { recommend international tourists who pay a visit of } \\
\text { cultural and wisdom tourism in People's Republic of } \\
\text { China. }\end{array}$ & $\begin{array}{l}\text { 2. Ministry of Education of People's Republic of China should increase } \\
\text { curriculum of teaching English for cultural tourism so that students } \\
\text { can learn English and contents of Chinese cultures at the same time. }\end{array}$ \\
\hline 3 & $\begin{array}{l}\text { Chinese Teachers did not hold sufficient experience } \\
\text { in using English in foreign countries, which affect } \\
\text { the way they can insert western languages and } \\
\text { cultures to Chinese students and cause students to be } \\
\text { in need of self-confidence in communicating with } \\
\text { foreigners. }\end{array}$ & $\begin{array}{l}\text { 3. The Chinese government should increase budgets for sending } \\
\text { Chinese teachers to attend more training about language and western } \\
\text { cultures teaching, both domestic and international levels. }\end{array}$ \\
\hline
\end{tabular}

\section{RESEARCH DISCUSSION}

A. The Summary of Opinion of Youths Who Live in Beijing Municipality, People's Republic of China towards the Importance of Using English to Elevate and Develop Cultural and Wisdom Tourism

It was found that Chinese youth leaders thought that English plays more important role in communicating with international tourists than any other international languages, at an extreme degree $(\overline{\mathrm{X}}=4.60)$. English plays an important role in elevating and developing China cultural and wisdom tourism at an extreme degree $(\overline{\mathrm{X}}=4.27)$. English is important to help tourists access in-depth information about Chinese cultures and ancient traditions, at a high degree $(\overline{\mathrm{X}}=4.17)$. Youths living in Beijing municipality, People's Republic of China are capable of using English to 
communicate and facilitate international tourists, at a high degree $(\bar{x}=4.10)$. Youths living in Beijing municipality, People's Republic of China are capable of using English to well describe information about cultural tourism, at a high degree $(\overline{\mathrm{X}}=3.93)$ respectively.

\section{B. The Summary of Chinese Youths' Opinion towards the Teaching and Learning Curriculum Management of English for Communication in Beijing Municipality, Secondary Education Level}

It was found that the level of opinion of Chinese youths towards the teaching and learning curriculum management of English for communication in Beijing municipality, secondary education level is at a high degree $(\overline{\mathrm{X}}=3.94)$. Teaching and learning management emphasizing English grammar is at an extreme degree $(\overline{\mathrm{X}}=4.83)$. Measurement and evaluation focusing on test scores achievement to further higher education level is at an extreme degree $(\bar{X}=4.43)$, and teachers have knowledge and skill in using English is at a moderate degree $(\bar{X}=3.60)$. Measurement and evaluation stressing on communication achievement is at a moderate degree $(\overline{\mathrm{X}}=3.53)$. The total hours of English subject earn sufficient credits to develop English skills are at a moderate degree $(\bar{X}=3.30)$. Teaching and learning management is efficient to enhance listening, speaking, reading, and writing skills at a moderate degree $(\overline{\mathrm{X}}=3.28)$, and teaching and learning management enhances students to practice and have hands-on experience to communicate with foreigners at a moderate degree $(\overline{\mathrm{X}}=3.25)$.

\section{The Summary of Level of Chinese Youths Opinion towards the Teaching and Learning Curriculum Management of English for Communication in Beijing Municipality, in a Higher Education Level}

It is found that the level of Chinese youths' opinion towards the teaching and learning curriculum management of English for communication in Beijing municipality, in a higher education level is at a high degree $(\overline{\mathrm{X}}=3.94)$. Teaching and learning emphasizing English grammar is at an extreme degree $(\overline{\mathrm{x}}=4.83)$. Measurement and evaluation focusing on test scores achievement to further study in a higher education level is at an extreme degree $(\overline{\mathrm{X}}=4.43)$, and teachers have knowledge and skills in using English is at a moderate degree $(\overline{\mathrm{x}}=3.60)$. Measurement and evaluation emphasizing communication achievement is at a moderate degree $(\overline{\mathrm{X}}=3.53)$. The total hours of English subject earn sufficient credits to develop English skills is at a moderate degree $(\bar{X}=3.30)$. Teaching and learning is efficient to enhance listening, speaking, reading and writing skills is at a moderate degree $(\overline{\mathrm{X}}=3.28)$. Teaching and learning enhances students to practice and have hands-on experience to communicate with foreigners at a moderate degree $(\bar{X}=3.25)$.

\section{In-depth Interview Outcomes from Chinese Youth Leaders}

The in-depth interview process management revealed that

1. Chinese youth leaders were aware of the importance of using English for communication in welcoming international tourists as it can greatly encourage tourism economy in Beijing municipality and other municipalities in People's Republic of China. They proposed to have regulations and increase of total hours of English subject for cultural tourism in economy and social development plan of People's Republic of China for 2016 - 2020. The problem that the research sample found was middle-aged people and the elderly hindered the learning of English and other international languages, which is considered a threat in developing the country in terms of tourism promotion.

2. Chinese youth leaders proposed the Chinese government to increase budgets for organizing English trainings or using innovation for self-study English learning so as to access the target group; the middle-aged people and the elderly. The training should be initially distributed to Beijing municipality and later to other municipality in People's Republic of China so as to develop teaching and learning English in parallel. The youths expect that if the Chinese government support those activities, people of all ages will be able to use English for communication better resulting in economic and social development as planned in economic and social development plan of People's Republic of China for 2016 2020 .

\section{Summary of ReseARCH Results}

After the study is completely conducted, the researcher can summarize the research results as follow:

1. The system and achievement of teaching and learning management of English as a foreign language is similar to that of both secondary and higher education levels.

Based on the research results, it can be assumed that teaching and learning management of English as a foreign language in People's Republic of China emphasizes students to majorly learn grammars, the learning achievement is based on measurement of test scores for studying further in a higher education level, it is not measured from achievement or capability of students in communication approach. Though credits or total hours of English learning are sufficient, without practicing to use communication skills, students do not have self-confidence in using English to welcome international tourists. The other interesting point is that educational institutes in People's Republic of China are without the training that enables youths to have hands-on experience to practice communicating with international tourists.

It is consistent with the research result from Xing Zioung, a researcher in educational approach, who made a field trip to study and find guidelines to problem solving of students in Beijing municipality who cannot use English for 
communication or for welcoming international tourists. The research result indicated that the reason that students did not have self-confidence in using English for communication was educational institutes received a policy from the Ministry of Education of People's Republic of China to stress on test scores achievement for studying further in a higher education level, at an extreme degree $(\overline{\mathrm{X}}=4.83)$.

It is also consistent with the research result from Houing Ching Zea, a researcher in educational approach from Western Language Institute, who conducted a research about problem solving of Chinese people who do not have selfconfidence in using English for communication though they averagely study English 10 years per person. The research result was spent 6 month for the researcher to make a field trip to collect data about English teaching and learning management in 3 secondary schools and 3 higher educational institutes. The research results indicated that English teaching system in People's Republic of China emphasized grammars and examination for studying further in a higher education level, at a high degree $(\overline{\mathrm{X}}=3.94)$. Meanwhile, teachers gave importance to encouraging students' capability to use English for communication with foreigners, at a low degree $(\overline{\mathrm{X}}=2.76)$.

With reference to the research results and examples of related research studies, it can be summarized that the Chinese government should increase the importance of creating a curriculum that focuses on using English for communication rather than a curriculum emphasizing grammars which results in students' achievement for being able to pass examinations for higher education level but students cannot use English for communication; it becomes a threat to opening the country and economic development of People's Republic of China by using tourism as a key mechanism.

2. Chinese youths are aware of the importance of integration in using English for promoting cultural tourism in Beijing municipality, People's Republic of China.

Based on the research results mentioned above, it can be assumed that Chinese youths are aware of the importance of using English for communication with international tourists. They agree that English is a key factor in elevating and promoting cultural tourism, which at present People's Republic of China is one of the top ranking countries in the world that foreigners pay a visit since they would like to study about cultures, traditions, and local wisdom that have been inherited for 1,000 years. Besides, the country has numerous world heritage ancient sites such as the Great Wall of China, etc.

It is consistent with the research result of Mo Khon Min, a Chinese researcher, who studied a potential of cultural tourism from 2000 - 2017. The research result revealed that the number of western tourist travelling to conservative tourism in People's Republic of China increased by 50 percent each year. This resulted in the economic growth that was increasing by leaps and bounds. However, one of the threats was Chinese people could not use English for communication, which had effect on tourists not to have convenience in travelling or communication, at an extreme level $(\bar{X}=4.37)$.

It is consistent with the research result of Myama Houng, a Chinese researcher in behavioral science in tourism, who surveyed opinions of European tourists about threats and problems found during travelling in People's Republic of China. The research result revealed that male European tourists required an increase of English information concerning travelling and transportation in the country, at a high degree $(\overline{\mathrm{X}}=4.17)$. It was in harmony with the information derived from female European tourists who required the police and information givers about tourism to be able to better use English as it could deliver contentment in travelling in the country, at a high degree $(\overline{\mathrm{X}}=4.10)$.

In relation to the research results and examples of research studies as mentioned above, it can be summarized that Chinese youths and new generation of people currently are aware of the importance of English teaching and learning management in a systematic manner that emphasizes students to be able to use English for communication with foreigners in their everyday life. If the numbers of Chinese people who can efficiently use English increase more than at present, a positive effect can happen to the economic growth of the country. Namely, international tourists can have relief and appropriate facilitation during their travelling in every municipality of the country. It results in the growing of economy and tourism that the Chinese government requires tourism industry to have higher GDP in 2020 by 5.92 compared to the revenue derived from tourism in 2017.

\section{REFERENCES}

[1] Anzar, U. (2001). An exploratory study of factor which have contributed to the Sustainabillity of community participation in education in balochistan. online www.thailis. Uni.net.th. [2016, October 10]

[2] Boonchom, S. (2002). Fundamental Research. (7th ed.). Bangkok: Suveeriyasarn.

[3] Boonprasert, M., et.al. (2003). Research and Higher Education Administrative System Development: A Contemporary of Higher Education Administrative Management. Bangkok: MPT.

[4] Daniel, S. (2003). Examination of the Relationship between School Board Governace, Community, and Superintendent Types. Dissertation Abstracts International. (1): 111-113).

[5] Jarernwongsak, K. (1998). Networking Management: Strategies to Successful Educational Reform. Bangkok: Success Media.

[6] Koomkhainam, T. (2007). Educational Administration Techniques. Chaiyaphoom, Chayaphom Rajabhat University.

[7] Kwantip, C. (2014). Strategies for Driving Basic Education towards ASEAN Community Retrieved December 9, 2014, from http://www.tcithaijo.org/index.php/Veridian-E-Journal/article/viewFile/17875/23391.

[8] Laddawan, P. (2011). Farmers's Collaboration in Keeping Family Expenditure and Income Record Account in Tambon Changpuek, Suwannapoom District, Roi-et Province, Management Science, Business Administration Graduate, Sukhothaithammathiraja. 
[9] Larbnongsang, S. (2012). Social Development for Thai people in the ASEAN community E-Journal, Journal of Education and Social Development, 8(1), 6-18.

[10] Longo, M. (2005). Recognizing the Role of Community in Cive Education: Lessons from Hull House. Highlunder Folk school and the Naghborhoob Learning Community. online www.eivicyouth.org/PopUps/Working/WP30Longo.pdf[2016, October 13].

[11] Ministry of Education. (2011). The Role of Education in Building an ASEAN Community 2015. Office of the Minister, Ministry of Education, Thailand.

[12] Moravec, J. (2007). A New Paradigm of Knowledge Production in Minnesota: University of Minnesota High Education: A Delphi Study. Dissertation Ph.D. Minnesota: University of Minnesota.

[13] Office of National Education Standards and Quality Assessment. (2007). Quality Assurance Report, Higher Education B.E. 2008-2011. Bangkok: Amarin Printing and Publishing.

[14] Prayoon, A. (2004). Networking and participation. Bangkok: Chulalongkorn University.

[15] Rajabhat University. (2010). Quality Assurance Handbook of Rajabhat University. Bangkok: LT Press.

[16] Ratanakorn, A. (2003). Indicators, Products, and Outcomes Rajabhat University. Bangkok, Jankasem Rajabhat.

[17] Thorn, S. (2003). The management-oriented reform: Theory, research and practice in education. Bangkok: Thailand Natick limited edition.

[18] Thira, R. (2013). As a professional in the preparation and administration of education reform. Bangkok: LT Press.

[19] Yonin, P. (2010). English for Writing Research Papers. Singapore: Springer.

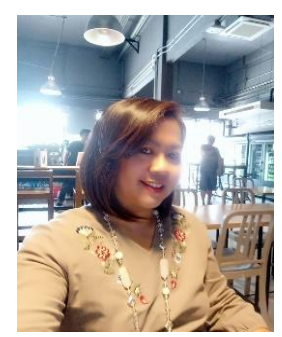

Onsiri Wimontham works for English Education, Faulty of Humanities and Social Sciences, Nakhon Ratchasima Rajabhat University, Thailand. She is interested in doing research in a field of TEFL and EFL Class. However, she is also interested in doing area based research. 